\title{
NP van Wyk Louw (1906-1970) \\ NP van Wyk Louw (1906-1970)
}

\author{
JC STEYN \\ Senior Navorsingsgenoot \\ Departement Afrikaans, Nederlands, Duits en Frans \\ Fakulteit Geesteswetenskappe \\ Universiteit van die Vrystaat \\ Bloemfontein \\ Suid-Afrika \\ E-pos: steynjaap@gmail.com
}

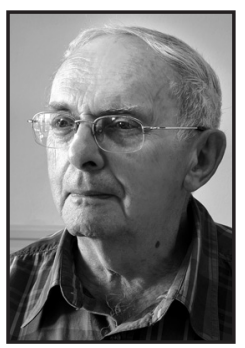

Jaap Steyn
JC STEYn het gestudeer aan die Universiteit van die Oranje-Vrystaat en die Gemeentelijke Universiteit van Amsterdam en was werksaam by Die Volksblad en Rapport, asook die Universiteit van Port Elizabeth (tans Nelson Mandela-Universiteit), die Randse Afrikaanse Universiteit (tans die Universiteit van Johannesburg) en die UOVS (tans die Universiteit van die Vrystaat). Hy het meer as 100 artikels in vaktydskrifte en boeke gepubliseer en is die skrywer van taalpolitieke en taal- en kultuurhistoriese werke. Die vernaamstes is Tuiste in eie taal (1980), Trouwe Afrikaners: Aspekte van Afrikaner-nasionalisme en Suid-Afrikaanse taalpolitiek 1875-1938 (1987), 'Ons gaan 'n taal maak': Afrikaans sedert die Patriot-jare (2014) en Verset en opbou: Skrywers en politici as aktiviste vir Afrikaans (2019). Ook in sy drie biografieë, Van Wyk Louw - 'n Lewensverhaal (1998), Penvegter - Piet Cillié van Die Burger (2002) en Die honderd jaar van M.E.R. (2004) gee hy besondere aandag aan die taalstryd en Afrikanernasionalisme. Onder sy ander publikasies tel die digbundel Die grammatika van liefhê (1975) en verskeie prosawerke, soos Sonkyker (2008). Hy is die ontvanger van etlike toekennings van die Suid-Afrikaanse Akademie vir Wetenskap en Kuns.
JC STEYn studied at the University of the Orange Free State (UOFS) and the Communal University of Amsterdam. He worked at the Afrikaans newspapers Die Volksblad and Rapport, as well as the University of Port Elizabeth (currently Nelson Mandela University), the Rand Afrikaans University (currently the University of Johannesburg) and the UOFS (currently the University of the Free State). He has published more than 100 articles in journals, and is the author of several books on language politics and language and cultural histories. The most important of these are Tuiste in eie taal ["A home in one's own language"] (1980), Trouwe Afrikaners: Aspekte van Afrikaner-nasionalisme en Suid-Afrikaanse taalpolitiek ["Loyal Afrikaners: Aspects of Afrikaner nationalism and the South African language policy] (1987), 'Ons gaan 'n taal maak': Afrikaans sedert die Patriotjare ["We're going to make a language': Afrikaans since the years of Die Patriot"] (2014) and Verset en opbou: Skrywers en politici as aktiviste vir Afrikaans ["Resistance and construction: Afrikaans writers and politicians as activists for Afrikaans"] (2019). In his three biographies, Van Wyk Louw - 'n Lewensverhaal ["Van Wyk Louw - A life story"] (1998), Penvegter - Piet Cillié

Alle gegewens kom uit Steyn (1998). Louw word aangehaal uit Louw (1986a) en (1986b), of uit ongepubliseerde bronne, waarby slegs die bladsynommer uit Steyn (1998) vermeld word.

\begin{tabular}{|c|c|}
\hline Datums: & \\
\hline Ontvang: 2020-01-12 & Goedgekeur: 2020-01-30 \\
\hline
\end{tabular}


van Die Burger ['Fighter with the pen' - Piet Cillié of Die Burger"] (2002) and Die honderd jaar van M.E.R. ["The hundred years of (the early Afrikaans author) M.E.R."] (2004) he paid special attention to the language conflict and Afrikaner nationalism as well. Among his other publications are a volume of poetry (Die grammatika van liefhe ["The grammar of love"] (1975) and several works of prose, such as Sonkyker ["Girdled Lizard"] (2008). He is the recipient of several awards from the South African Academy of Science and Art.

\section{ABSTRACT \\ NP van Wyk Louw (1906-1970)}

NP van Wyk Louw is the only Afrikaans writer whose work has been awarded the Hertzog Prize, the most prestigious Afrikaans literary prize, five times. This is an indication of his stature in the Afrikaans cultural community. Karel Schoeman called him South Africa's greatest poet and one of the few world-renowned figures the country has ever produced. The historian Hermann Giliomee believes that Louw's equal as author of essays on cultural politics has not been seen in this country yet.

Nicolaas Petrus van Wyk Louw, born on 11 June 1906, was the second of four sons of Bismarck von Moltke Louw (1874-1949), a lawyer of Sutherland, and Martha Hendrina Johanna Frederika (Poppie) van Wyk(1882-1970). The youngest son was the poet WEG Louw (1913-1980).

Their home language and the colloquial language was Afrikaans, but early on Louw became acquainted with English and Dutch. The Dutch Statenbijbel ("State Bible") and the Dutch hymn book were still in use in the church and in households, and his grandfather Van Wyk was able to pray in almost flawless Dutch. Louw later said he remembered that, by analogy of the hymn book, he wrote two lines in very poor Dutch. Even before he was eight years old, Louw felt that what he wanted to do above all was to write poetry.

English was the language of instruction when Louw started school in 1911. He regularly visited the town library and from his tenth year consulted the Encyclopaedia Britannica. The well-equipped library housed only English books, apart from WJ Conradie's Kinderbybel ("Children's Bible"). Louw "devoured" history books and literary works.

In December 1920, the Louw family relocated to Cape Town. Louw attended the South African College School (SACS), and after finishing school he enrolled at the University of Cape Town, majoring in Latin, German, Dutch and Afrikaans. Next, he completed a master's degree in German and, after teaching for a year in the small Eastern Cape village of Steynsburg, completed a BEd degree. In 1930, Louw was appointed as a lecturer in the bilingual Faculty of Education at UCT, and in the same year he married Joan Wessels (1906-1975).

By 1930 some of Louw's poems had been published in the Kwartaalblad, but his first manuscript for a volume of poetry had been rejected for publication by a literary critic. This criticism was such a blow to Louw's confidence that he temporarily stopped writing poetry. When his youngest brother, Gladstone, set eyes on those poems, he realised their value. After four years, Louw started to write again. His debut poetry collection, Alleenspraak ("Monologue"), was published in 1935. 
Even before the publication of Alleenspraak, Louw, as a public intellectual, started to write more and more about matters affecting Afrikaans and the Afrikaner. From 1935, he started writing about Afrikaans authors and their national aspiration. For Louw, politics was an essential aspect of the language struggle, but for a national movement by the people it was, in his view, merely a technical means to achieve a set goal. Without the creation of a meaningful literature, the language movement and the accompanying political movement would have made no sense. His articles were collected in the volumes Berigte te velde ("Reports from the field") and Lojale verset ("Loyal resistance") in 1939. The latter includes the well-known slogan that revolt is as essential to a nation as loyalty. It is not really dangerous when a rebellion fails; what is dangerous is that an entire generation might pass without protest. These two volumes had a major influence on the intellectual life of Afrikaners.

Some of Louw's major nationalistic poems were included in his second anthology, Die halwe kring ("The half-circle"; 1937), and in his choral drama Die dieper reg ("The deeper right"; 1938), which has a nation's right to continued existence as theme. The Dutch-born HA Mulder was of the opinion that the volume Die halwe kring ranks with the major Dutch lyrical collections of poems as their equal. It was awarded the Hertzog Prize. His following works, Raka (1941) and Gestaltes en diere ("Figures and animals"; 1942), were received very well and are regarded as high points of Afrikaans poetry. Literary critics such as AP Grové highlight the spectacular development of Louw's poetry since Alleenspraak. In the 1940s, he started writing his verse drama Germanicus as well (1956; in 1960 it was awarded the Hertzog Prize) and later he also wrote several radio dramas. Since 1937, Truida Pohl had been an inspiration in his life. They were married in 1941 after his divorce from his first wife. Two children were born of this marriage: Reinet (1946) and Peter (1950).

During the 1940s, Louw wrote numerous literary articles; he and Truida worked for Afrikaans radio, and, together with his brother Gladstone, they founded the literary journal Standpunte ("Points of view"), in which he also published articles. Although he later became an outspoken critic of apartheid, in 1946 he pointed out the powerlessness into which Afrikaners and English speakers would sink and the danger of cultural suicide that could result if liberal principles were introduced unqualifiedly in South Africa.

In 1948, the Rijksuniversiteit of Utrecht awarded him an honorary doctorate to acknowledge the interest in and great appreciation of the Dutch humanities for the developments in the latest Afrikaans literature, of which, the commendation read, he was the leader and symbol.

In 1949, Louw accepted an appointment as professor in "Zuidafrikaanse taal- en letterkunde" (South African language and literature) at the Gemeentelijke Universiteit of Amsterdam. His wife and children could not leave with him, and while on his own in Amsterdam a love affair developed between him and the poet Sheila Cussons. This relationship was not always close, but for Louw it was a creative stimulus. Without Sheila Cussons many of the poems in Nuwe verse ("New poems"; 1954) and Tristia (1962) would never have been written.

During his years in Amsterdam, he also wrote the series "Die oop gesprek" ("The open conversation"), which appeared in the popular weekly Die Huisgenoot from 20 July 1951 until 18 December 1953. Many of the essays in that magazine dealt with literary themes, the most influential of which being the series "Die 'mens' agter die boek" ("The 'person' behind the book"). They were aimed at psychologism in literary views and criticism.

In "Kultuur en krisis" ("Culture and crisis"), he explains the crises that can befall a nation. The first is that of physical annihilation; the second, the crisis of despair. This latter crisis occurs when many members of a community feel that it is not worthwhile to continue 
as a group with its own language. Finally there is an ethical crisis, which entails the belief that mere survival is preferable to survival in justice.

The articles in Die Huisgenoot and other essays were published in 1955 under the title Maskers van die erns ("Masks of earnestness") and in 1958 in three further volumes: Swaarteen ligpunte ("Centres of gravity and luminosity"), 'n Wêreld deur glas ("A world through glass) and Liberale nasionalisme ("Liberal nationalism"). The first-mentioned and Die mens agter die boek (1956) formed part of the collection of critical prose and essays that earned him the Hertzog prize in 1958.

Louw received this news in June 1958, shortly before he departed for South Africa to take up the position of head of the Department of Afrikaans and Dutch at the University of the Witwatersrand.

In 1962, Tristia was published. This title refers to a volume by the Roman poet Ovid, written during his exile. Gerrit Olivier points out what he called the unbelievably complex richness of Louw's Tristia. According to Grové, Tristia contains some of the most mature and profound poems in Afrikaans. His inaugural address at Wits, "Oor moeilike literatuur: die "verwysingsmoeilikheid" ("On difficult literature: the problem of reference") in 1959 is virtually a theoretical guide to Tristia. The volume was awarded the Hertzog prize for poetry in 1965. In his address of commendation at the award ceremony, TT Cloete stated that with Tristia Louw's mastery as poet, which again and again proved to be surprising, once again took a new direction. He added that Louw remained, together with much younger poets, one of the "youngest" poets in the country.

Cloete referred to the work of the new literary generation: the authors of the 1960s ("die Sestigers"). Louw went to great lengths to combat misconceptions about prose and innovation. His articles are contained in Vernuwing in die prosa ("Renewal in our prose"; 1961). Etienne Leroux stated that Louw's treatment of his first books was an incentive for him to continue his writing.

In 1965, Louw stepped into the breach for another poet of the 1960s, Breyten Breytenbach. The government had refused a visa for Breyten's wife, Yolande, to visit South Africa because she was born Vietnamese. In a letter to a newspaper Louw criticised the government "as an Afrikaner", but also on behalf of the Afrikaans literature, which, he said, had its own honour and dignity. He was pained and ashamed because the Afrikaans nationalism in which he grew up and in which he hoped to die was, for him, the greatest movement in our history and a sign of growth, of an increasingly full life. Had this, he asked, turned into a petrified ideology that officials could measure with a carpenter's rule?

Louw wrote various pieces for special occasions. The most controversial was Die pluimsaad waai ver ("The plume seeds are blown far"), which was performed during the Republic Festival in 1966. It starts with the question of what a nation is. In Pluimsaad all those who in the Anglo-Boer War participated on the side of the Free State belonged to the Free State Afrikaners. They included, apart from the Afrikaners, also English speakers, Cape rebels, Dutchmen and coloured people. The literary critic Merwe Scholtz regarded the drama as a "broad democratic definition of the Afrikaner nation". The performance elicited much criticism in 1966 - in a Republic Festival speech from the Prime Minister, Dr HF Verwoerd, as well. Most of the letters to newspapers were pro-Louw, however, and some important personages came to his defence.

On 13 November 1961, Louw had a serious heart attack and from then on suffered heart trouble. Early on the morning of 18 June 1970 he died - a week after his 64th birthday and three weeks after the death of his eldest brother, Koos, to whom he was very close. Their mother, the 88-year-old Poppie, who was bedridden after a stroke, died on 28 July. 
Louw remains relevant in the literary and cultural life of South Africa. His works remain alive in intertextual references, citations, parodies and titles, for instance in the works of Breyten Breytenbach, Sheila Cussons, Johan van Wyk and Joan Hambidge.

After 1970, "Kultuur en krisis" was a theme in the political debate. Giliomee writes that Louw's phrases regarding continued existence in justice and loyal resistance were freely used in the public debate during the 1970s - in his opinion often opportunistically. Breyten Breytenbach quoted the former phrase during his trial in 1975. Even before Breytenbach came to South Africa to establish a structure for an underground movement, certain ANC leaders informed the security police. He was arrested, and during his trial he invoked Louw in a desperate plea: "It may be paradoxical, but for me the very point was the survival of our people, survival in justice as Van Wyk Louw put it, it was about the quality and content of our civilization" [own translation]. The judge did not take any note of this.

Afrikaners nowadays find themselves amidst the second kind of crisis that Louw distinguished: the crisis of despair, despair which is the result of emigration and Anglicisation, of the ideology of "transformation" and of the disregard for language rights by antagonistic authorities. In the discourse about this situation, Louw's views on such a crisis and on the response of people of culture to that crisis gain new significance and relevancy.

KEYWORDS: $\quad$ NP van Wyk Louw; Afrikaner nationalism; Breyten Breytenbach; Afrikaans poets of the 1930's; Hertzog prize

TREFWOORDE: NP van Wyk Louw; Afrikaanse nasionalisme; Breyten Breytenbach; Dertigers; Hertzogprys

\section{OPSOMMING}

Ná die verskyning van Van Wyk Louw - 'n Lewensverhaal het meningsverskil oor bepaalde aspekte daarvan ontstaan. Onder meer is aangevoer dat Sheila Cussons (wat nie met my wou praat nie) 'n groter rol in Louw se Amsterdamse jare gespeel het, en ook dat ek negatiewe eienskappe en optredes van hom nie sterk genoeg stel nie, al is dit nie verswyg nie. Ek begin sy lewensverhaal met die oordeel van Karel Schoeman dat Louw "een van die min figure van wêreldformaat is" wat die land nog opgelewer het. Van só 'n mens lê jy nie die klem op sy swakhede nie, maar op sy betekenis vir die Afrikaanse letterkunde, die Afrikaanse gemeenskap, die hele Suid-Afrikaanse samelewing. Wat hy oor nasionalismes, taalbewegings, klein volke en tale skryf, bly aktueel. My bedoeling met die boek was om die lewensverhaal van 'n interessante man, 'n groot digter en denker, so waarheidsgetrou en ewewigtig as moontlik te vertel.

\section{INLEIDEND}

NP van Wyk Louw is die enigste Afrikaanse skrywer wie se werk vyf keer met die Hertzogprys bekroon is. Dit is ' $n$ aanduiding van sy statuur in die Afrikaanse kultuurgemeenskap. Karel Schoeman noem hom Suid-Afrika se grootste digter en een van die min figure van wêreldformaat wat die land nog opgelewer het (1986:187). Hermann Giliomee oordeel dat Louw as skrywer van essays oor kultuurpolitiek vandag nog nie sy gelyke het nie (2004:381). Giliomee wys telkens in sy geskiedenis van die Afrikaners op die invloed van Louw se denke op die politieke debatte.

Polities en literêr was Louw dikwels omstrede. Dit blyk ook uit meningsverskille oor die Hertzogpryse wat aan hom toegeken is en waaroor daar in die slotafdeling van hierdie lewenskets verslag gedoen word. 
Louw is gebore en getoë op die klein Roggeveldse dorp Sutherland. Sy vader, Bismarck von Moltke, of "Molkie" (1874-1949), was 'n prokureur. Hy is in 1904 getroud met Martha Hendrina Johanna Frederika van Wyk, beter bekend as Poppie (1882-1970). Die oudste van hul vier seuns was Jacobus Adriaan, Koos (1905-1970), gevolg deur die latere digter Nicolaas Petrus van Wyk op 11 Junie 1906, Bismarck von Moltke (1909-1945) en William Ewart Gladstone (1913-1980), die digter WEG Louw.

Die Louws was welgesteld en het vier mense heeltyds vir die huishouding in diens gehad: 'n wit en 'n bruin meisie vir die huis, 'n wit man vir die tuin en 'n bruin man, Barend, wat na die perde moes kyk. Dit is "Bêrend, die jong" van die gedig "Beeld van 'n jeug: Duif en perd".

Die huistaal en algemene omgangstaal was Afrikaans, maar Louw het vroeg kennis gemaak met Engels en Nederlands. Die Nederlandse Statebybel en Psalm- en Gesangeboek was nog in die kerk en huisgesinne in gebruik en Louw se grootvader Van Wyk kon gebede in byna foutlose Nederlands doen. Taal het Louw in sy jeug al geboei en dié belangstelling is geprikkel deur die taal wat hy tydens vakansies op die Van Wyk-plaas Gunsfontein kon hoor. Daar was "speel-met-taal" 'n "hoë vorm van vermaak" - rympies; raaisels; woordspeletjies; stories vertel; terg en pla; en die uitdink en smaaklike gebruik van byname (Louw 1986a:539). Wit en bruin mense het baie kontak met mekaar gehad. Die twee groepe se taal het nie verskil nie.

Hy het dit altyd as 'n groot geluk beskou dat hy kon grootword in 'n streek waarin Afrikaans "byna heeltemal ongerep en skoon was". Engels het feitlik geen invloed op die spreektaal gehad nie. Die distrik Sutherland het volgens sensussyfers die kleinste Engelssprekende bevolking in die land gehad. Daar het ' $n$ sterk Afrikaanse gesindheid bestaan, wat aangewakker is deur 'n paar taalbewuste leiers, soos ds. WJ Conradie, skrywer van die eerste Afrikaanse Kinderbybel, en ná hom dr. BR Hattingh (wat Louw gedoop het) asook die skoolhoof EC Pienaar. Hattingh was een van die predikante wat vroeg reeds Afrikaans op die kansel gebruik het. Dit is veelseggend dat die notules van die afdelingsraad van Desember 1897 af in Nederlands gehou is ondanks die sterk neiging om alles met 'n offisiële kleur in Engels te doen.

Engels was egter nog die voertaal toe Louw en sy ouer broer Koos in 1911 in die skool kom. Die provinsiale ordonnansies rakende moedertaalonderrig (1912) en Afrikaans - in plaas van Nederlands - vir Afrikaanssprekendes (1914) is, soos in die meeste Kaaplandse skole, nie dadelik toegepas nie. Die man wat in die skoolraad die gelyke behandeling van Afrikaans en Engels voorgestel het, was Moltke Louw.

Louw het die dorpsbiblioteek gereeld besoek en van sy tiende jaar af die Encyclopaedia Britannica geraadpleeg. Engelse boeke het hy mettertyd "verslind”. Die redelik goed toegeruste biblioteek het hom 'n blik gegee op 'n groter wêreld as wat hy andersins op Sutherland kon leer ken. In 'n lys het hy later werke genoem soos Stories from Greek History, Stories of Roman History, Greek Myths \& Legends, Stories from Scottish History en TB Macaulay se Critical and historical essays, wat vir hom "byna 'n ensiklopedie van 'n deel van die Europese kultuur" was. Hy noem ook 'n History of Rome en die Works of William Shakespeare.

In 'n stadium het hy byna elke boek in die vorm van 'n "mono-toneel" opgevoer en op die erf uitgespeel. Met stokkies in die grond het hy die veldslae van die Grieke en Romeine gerekonstrueer. Hy het William H Prescott se History of the conquest of Mexico besit. Dit is die boek waaraan die jong seun in "Beeld van 'n jeug: Duif en perd" dink wanneer hy 'n oomblik opkyk van die Romeinse geskiedenis wat hy tussen sy duiwe in die agterplaas lê en lees. In die kantlyn van 'n gedeelte van die boek waarin die skrywer die Spaanse onderdrukking van die opstand teen die Spaanse koloniale bewind goedpraat, skryf die jong Louw: "nee!" Dit is eintlik sy eerste verwerping van kolonialisme. 
Nederlands was 'n skoolvak, maar die voorgeskrewe Bloemen uit de Nederlandse tuin het hy ervaar as 'n "woestyn van dorheid" sonder die honderde mooi gedigte van ná 1880 . Uit radeloosheid het die onderwyser een oggend die boek toegeslaan en vir die leerlinge "Die Vlakte" van Jan FE Celliers voorgelees. Dit was vir hulle "die oopgaan van 'n nuwe wêreld, of liewer ons eie oë het oopgegaan om ons Karoo-wêreld nuut te sien" (Louw 1986b:197). Die enigste Afrikaans in die dorpsbiblioteek was Conradie se Kinderbybel. Op sy tiende verjaarsdag in 1916 het Louw van sy pa as geskenk die stuk of agt dele van Melt Brink se Grappige verhale en ander versies gekry.

Reeds voordat hy agt jaar was, het Louw gevoel dat wat hy bowenal wou doen, was om gedigte te skryf. Die Nederlandse godsdienstaal was die medium van sy eerste poging. "Ek onthou dat ek na analogie van die Psalm- en Gesangbundel twee reëls gemaak het in baie swak Nederlands:

Om ons te brengen op het pad

dat Hy ons lang beloven had. (24)

Louw vertel dat hy as jong seun slegs swak Engelse en Nederlandse verse te lese gehad het. “Gelukkig het 'n eie sintuig vir goeie poësie my baie jonk al, 'n liefde laat kry vir ons oudste poësie: vir sulke lieflike dinge soos ons: 'Staan Pollie, staan Pollie / Hand in die sy'. Toe ek dus so vyftien, sestien jaar oud, in die Europese literatuur óók sulke volkspoësie ontdek het, het ek self daarvan begin maak" (25).

In Desember 1920 is die Louw-gesin na Kaapstad. Deels was dit ter wille van oom Molkie se gesondheid, deels ter wille van die kinders se opvoeding. Uit "die 'volpoëtiese' Rôeveldse lewe" is hy en sy broers oorgeplaas na "die saaklike, abstrakte en (destyds nog) volkome Engelse wêreld van Kaapstad” (Louw 1986a:588). Aangesien daar nog geen Afrikaanse skole in Kaapstad was nie, is Louw en Koos na die South African College School (SACS). Hulle was toe in standerd 9 (graad 11). Op die tweetalige skool in Sutherland het Louw goed gevaar in Engels. Hy kon dit met gemak lees, maar die praat was moeiliker. Ondanks sy kennis van Engels was die twee jaar in 'n Engelse skool vir hom 'n "swaar tyd" (30).

Die Louw-seuns se wêreld het al hoe meer Engels geword en bowendien was hul ouers "Sappe", dit wil sê ondersteuners van die Suid-Afrikaanse Party (SAP) wat al hoe meer verengels het namate gewese Unioniste (almal Engelssprekend) hulle daarby aangesluit het. Maar die seuns se Afrikaanse gesindheid is in die wintervakansie van 1921 en vakansies daarna versterk deur besoeke aan die Louw-familie van Calvinia, veral van die plaas Soetwater. In die Anglo-Boereoorlog was hulle aan die Boerekant. In die rebellie van 1914 was verskeie lede van die Louw-familie in die gevangenis weens hul teenstand teen die inval in DuitsSuidwes-Afrika.

In 1921, sy eerste jaar op SACS, is Louw se eerste lang vers gepubliseer. "Bij een Siekbed" in De Goede Hoop van 15 November 1921 gaan oor die pampoentjies wat hy opgedoen het. Op een klein foutjie na was die vers grammaties in orde, sonder toegewings aan "digterlike vryheid". Selfs voordat hy 'n versreël in Afrikaans geskryf het, het hy gevoel dat 'n digter wat 'n taalfout maak, "'n knoeier is soos 'n komponis wat 'n bepaalde noot nie kan herken nie" (Louw 1986a:542). Gestimuleer deur sy voorgeskrewe werk en die volkstaal van Soetwater skep hy aan die einde van sy matriekjaar sy eie Twelfth Night. Hy het die "poësie van ons eie Afrikaanse plattelandse lewe" deur Twelfth Night ontdek (Louw 1986b:537). In die tyd het hy volksliedjies begin opteken.

Louw het matriek in die eerste klas geslaag met 'n A-simbool vir Latyn. Sy ander vakke was Nederlands, Engels, wiskunde, geskiedenis en skeikunde. Van 1923 af was hy student 
aan die Universiteit van Kaapstad. Die BA-graad was anders gestruktureer as tans en hy het Latyn, Engels, Nederlands en Afrikaans en dierkunde in die eerste jaar gehad, in sy tweede jaar Latyn II, Psigologie I en Duits I. Naas Duits II was Nederlands en Afrikaans II en Latyn II sy hoofvakke. Sy kursus het verder Etiek I ingesluit. Sy denke is steeds beïnvloed deur Engelse skrywers soos Robert Burns en veral Thomas Carlyle (On heroes, Hero-worship) en Shakespeare. Duits en kort daarna Frans, het hy in 'n kort tyd baasgeraak. Duits was nie op Sutherland 'n skoolvak nie en hy het eers in sy eerste jaar daarmee begin. Duits het hy veral geleer deur boek na boek te lees, "sonder woordeboek, eers in newels en algaande tot helderheid" (50-51). Kort nadat hy met dié taal begin het, het hy Heine en Goethe gelees, gou ook Rainer Maria Rilke en Stefan George. Hölderlin het hy hooggeag en hom beskou as 'n suiwerder digter as Goethe. Die Duitse invloed is sterk in Louw se vroeëre werk wat gepubliseer is in die tweetalige Kwartaalblad van die Universiteit van Kaapstad, soos 'n drama, getitel Konrad, prins van Elsas, in Oktober 1924. Een van die groot belewenisse van sy jeug was vir Louw die ontdekking van die groot geeste van ook ander tale. "En dink net, om binne twee jaar en as jy jonk is, vir Vergilius en Shakespeare en Goethe en die moderne Nederlandse meesters te ontdek!" (Louw 1986b:536). Daarby was hy veelsydig - in sy skooljare het hy so goed gevaar met sy klavierlesse, ook in openbare eksamens, dat die familie gedink het hy kan van musiek 'n loopbaan maak.

Aanvanklik was Louw van plan om Nederlands en Afrikaans as sy hoof-studierigting te kies, maar het in 1926, sy vierde jaar op universiteit, die MA-klasse in dié vak en in Duits bygewoon. Hy het egter net die eksamen in Duits afgelê. Sy geesdrif vir die nuwe wêreld wat deur Duits geopen is, het waarskynlik tot die besluit bygedra. Hy was nog nie goed bekend met die moderne Nederlandse poësie, wat hy en sy vriende later so bewonder het nie.

In 1927 was hy onderwyser op Steynsburg: Duits van standerd 7 tot 10 en Engels vir standerd 7 en 8 . Die leerlinge se vorige onderrig in Duits was so swak dat hy baie ekstra klasse moes gee. In 1928 is hy terug na die universiteit en studeer hy vir 'n Secondary Teacher's Higher Certificate, asook vir die graad BEd. In 1929 het Louw 'n tydelike en van 1930 af 'n vaste aanstelling as lektor gekry in die tweetalige Fakulteit Opvoedkunde; hy moes in 'n hele paar vakke les gee deur medium van Afrikaans en Engels. Die betrekking het hom in staat gestel om op 18 September 1930 in die Groote Kerk in Kaapstad te trou met Joan Wessels (1906-1975). Uit die huwelik is twee dogters gebore: Maria Johanna (1932-1964) en Anna Cornelia (1933-1984).

Teen hierdie tyd was Louw 'n oortuigde Afrikaanse nasionalis. In sy skool- en studentejare is die grondslag gelê van sy latere denke oor Afrikaans en die Afrikaners. In sy matriekjaar het Louw sy oorgang na Afrikaans "absoluut soos 'n bekering ondergaan”. Heel moontlik was dit 'n taalpolitieke bekering teen die gebruik van Engels as latere huistaal en die vermenging van Afrikaans en Engels waarvoor baie Kapenaars so lief was. Hy het op besoeke aan Gunsfontein familielede betig wat 'n onnodige Engelse woord in hul gesprekke gebruik het. Deels was die bekering van partypolitieke aard weg van sy ouers en die Sutherlandse familie se ondersteuning van die "Sappe".

In die algemene verkiesing van 1924 was hy 'n ondersteuner van die Nasionale Party van genl. JBM Hertzog. Wat 'n groot indruk op hom gemaak het, was 'n toneel by die Kaapstadse stasie met die aankoms van Hertzog. 'n Bruin man het op die modderskerm van die motor gespring waarin Hertzog gery het, en aanhou roep: “Ons Generaaltjie! Ons Generaal!". Sommige bruin kiesers het die Nasionale Party en sy bondgenoot, die Arbeidersparty, gesteun. 


\section{DIGTER EN DENKER}

Enkele gedigte van Louw het in die Kwartaalblad verskyn en in 1931 lê hy 'n bundel, getitel "Dramatiese lyriek en impressies" voor aan dr. FCL Bosman. Hy beskou dit egter as heeltemal ongeskik vir publikasie. JC Kannemeyer meen tereg dat Bosman Louw onwetend 'n guns bewys het. As sy bundel in daardie vorm verskyn het, sou sy debuut veel swakker vertoon het teenoor Deining van CM van den Heever en Die ryke dwaas van WEG Louw. Maar Bosman het onsensitief op die gedigte gereageer en sy kritiek het Louw se selfvertroue so geknou dat hy nog dikwels onseker was of hy 'n bundel moes uitgee of nie (Kannemeyer 1990:21-23). Louw mak melding (1986a:162) van 'n kunstenaar se martelende afwisseling van geloof in die waarde van sy werk, en die twyfel daaroor.

Louw het in 1931 dus opgehou met gedigte skryf en aan 'n proefskrif in die opvoedkunde begin werk (maar dit nooit voltooi nie) en planne gemaak vir prosa- en dramatiese werk. Maar veral het hy al hoe meer opgegaan in die filosofie. Dié belangstelling sou sy hele lewe duur. Kort voor sy dood sê hy die enigste vraag, sy hele lewe lank, was: "Wat is wáár? Wat kan ek wéét, wat kan ek glo? Waaraan kan ek vashou?" Hieruit het voortgekom sy swerftogte deur filosofieë en ideologieë, en iets daarvan moes "afgesmeer het” aan sy werk (Louw 1986a:586).

Gelukkig kon sy jongste broer Gladstone hom van die twyfel oor sy digterskap verlos. Hy het Duits-lesse by Louw geneem en een aand, ná die les, het Louw na aanleiding van verse van Gladstone in die nuutste Kwartaalblad gesê: "Ek sien jy skryf ook verse." "Óók? Skryf jy dan óók?" (WEG Louw 1972:4). Louw het hom vertel wat gebeur het en Gladstone het die afgekeurde verse gaan lees en die waarde daarvan besef. Volgens hom het Louw ná vier jaar weer begin skryf. Louw se debuutbundel, Alleenspraak, het in 1935 verskyn. In resensies is dit vergelyk met sy broer se Die ryke dwaas en laasgenoemde is hoër aangeslaan.

Saam het die broers verse in Afrikaans en ander tale gelees. Gladstone sê in sy "Naggesprek": "Ons het ons in die literatuur geweek; / dit verwerk en in ons opgeneem soos kos - / byna bedoelingloos..." (WEG Louw 1972:8). By die jong boekhandelaar Gerrit Bakker kon die Louw-broers en Izak van der Merwe (Boerneef) die nuutste Nederlandse digbundels bestel en met bewondering lees. Die literêre vriendekring het groter geword: Anna NeethlingPohl, eggenote van Chris Neethling, en haar suster Truida, Fred le Roux, J du P Scholtz, Hettie Smit. Hierdie vriende se gesprekke oor die letterkunde het gelei tot ' $n$ beweging om die literêre lewe te hervorm deur onder meer die Vereniging vir die Vrye Boek (VVB), waarvan Louw die sekretaris was. Die VVB se oogmerk was die bevryding van Afrikaanse manuskripte wat moontlik deur gevestigde uitgewers geweier sou word omdat hulle nie betalend sou wees nie.

Nog voor die publikasie van Alleenspraak het Louw al hoe meer as openbare intellektueel oor sake geskryf wat Afrikaans en die Afrikaner raak. Die opvoedkunde het hom gelei na die opvoedkundige agterstand van die Afrikaners, een van die vernaamste oorsake van die armblanke-vraagstuk wat in die 1930's een van die grootste kwessies in die Suid-Afrikaanse politieke en sosiale lewe was. Dit het hom gedwing om te lees oor die ekonomie, sosiologie, staatswetenskap en die wysbegeerte. Sy eerste gepubliseerde artikel was uitvoerige besprekings in Die Huisgenoot (19 Mei 1933 en 15 September 1933) van die Carnegie-verslag van 1932 oor blanke armoede (107-110).

Van 1936 was taal en letterkunde die temas van Louw se skryfwerk in koerante en tydskrifte. In die jeugblad, Die Jongspan, het hy anoniem 'n nuusoorsig, "Wat oral gebeur", behartig. Daarin het hy sy lesers ingelig oor Suid-Afrikaanse en internasionale gebeure, maar ook oor die Vlaamse, Tsjeggiese, Turkse, Walliese en Friese taalstryde en dit steeds in verband gebring met die Afrikaanse taalbeweging en taalstryd. 
Onder sy naam het hy in Die Burger en sy politieke opponent, Die Suiderstem, asook algemene tydskrifte, veral Die Huisgenoot, maar ook sy mededinger, Die Brandwag, oor die jonger skrywers en hul nasionale strewe geskryf. Só verskyn op 5 Junie 1936 in Die Huisgenoot "Die rigting van die Afrikaanse letterkunde" wat beskou word as 'n manifes van die digters van dertig. Hierin staan begrippe voorop soos "volledige menslikheid binne volksverband". Die eise wat 'n mens aan die literatuur stel, sluit in "eerlike, strenge, deur-dink van die lewe", die gebruik van "die rykste verskeidenheid" woorde en beelde uit die hele lewe, woord- en vorm-suiwerheid en "onmiddellikheid voor God". Die Afrikaanse literêre beweging moes loskom van 'n koloniale mentaliteit wat sy leiding ontvang van Europa of Brittanje.

Afrikaanse nasionalisme impliseer ' $\mathrm{n}$

vurige meeleef met alles wat in die volk omgaan; dis 'n liefde vir die dinge wat die volk trotser en bewuster maak, wat hom stoflik ook sterker maak; dis 'n medelye met swaarkry en stryd teen dié wat hom laat swaar kry; dit is bitter haat teen alles wat kleinlik in die volk is en alles wat sy trots aantas en hom kleineer. Dit is die vaste wil om na eie kragte en buite alle loon om iets te doen wat die geestelike besit van die volk sal verryk. (Louw 1986a:45)

Die politiek is vir Louw 'n noodsaaklike aspek van die taalstryd, maar dit is vir 'n volksbeweging “alleen 'n tegniese middel om 'n gestelde doel te bereik" (Louw 1986b:223). Sonder die skepping van 'n waardevolle literatuur sou die taalbeweging en die gepaardgaande politieke beweging vir Louw geen sin gehad het nie. Die strewe om 'n Afrikaanse gemeenskap met 'n eie taal te bly, kan net geregverdig word "deur die rykdom van onvervangbare waardes wat ons in dié taal voortbring” (Louw 1986a:164). Dit lei tot die gevolgtrekking: "As ons nie in Afrikaans so 'n letterkunde kan skep dat ons vir elke mens, selfs die beste geeste wat by ons gebore sal word, sy diepste verlange kan bevredig nie, as ons hom nie iets kan gee wat hy in geen ander taal kan kry nie, dan moet ons in alle eerlikheid ons stryd om die behoud van ons taal staak as 'n gevaarlike partikularisme, want dan sal dit die Afrikaanse mens in sy ontwikkeling knel" (ibid).

Hierdie artikels is in 1939 in die twee bundels Berigte te velde en Lojale verset opgeneem. Laasgenoemde bevat die bekende leuse: “Opstand is net so noodsaaklik in 'n volk as getrouheid. Dit is nie eens gevaarlik dat 'n rebellie misluk nie; wat gevaarlik is, is dat 'n hele geslag sonder protes sal verbygaan" (Louw 1986a:66). Dié boeke het 'n groot invloed op die intellektuele lewe van die Afrikaners gehad.

Die Afrikaanse nasionalisme het in 1938 een van sy hoogtepunte beleef met die simboliese ossewatrek van verskeie plekke af na die terrein van die Voortrekkermonument waarvan die hoeksteen op 16 Desember 1938 gelê is. Die Volksteater-vereniging van Pretoria het 'n versoek gekry om 'n kort stuk oor die Groot Trek op te voer. Omdat daar nie so 'n stuk was nie, het Anna Neethling-Pohl, wat verbonde was aan die vereniging, Louw gevra om 'n stuk te skryf. Dit was die koorspel, Die dieper reg, wat dikwels opgevoer en in 1938 as boek uitgegee is. Die tema is die reg van 'n volk om voort te bestaan.

Sommige van Louw se groot Afrikaner-nasionale verse is opgeneem in sy tweede digbundel, Die halwe kring (1937). Hieronder is "By die monument" en "Miskien ook sal ons sterwe" in die groep "Gedagtes, liedere en gebede van 'n soldaat". Hierdie twee gedigte is in die vroeë 2000's op die terrein van die Nasionale Vrouemonument in Bloemfontein op plakkette aangebring.

Dié digbundel bevat verder die pragtige "Vier gebede by jaargetye in die Boland". Hierdie natuurverse kan ook gelees word as liefdesgedigte en só het Louw hulle inderdaad bedoel. Hy 
het verlief geraak op Truida Pohl (1913-2004), verbonde aan die redaksie van Die Jongspan. Hy het die gedigte netjies oorgeskryf en aan haar besorg. Sy was getroud met Fred le Roux. Truida het van hom geskei. Ook Louw en sy eggenote, Joan, is geskei. Die breuk het gelei tot 'n krisis in die familieverhoudings. Die verhouding is meer as drie jaar later herstel met die hulp van Gladstone, wat die optrede van sy broer aanvanklik skerp veroordeel het. Louw en Truida is op 10 April 1941 voor die magistraat getroud en twee kinders is uit die huwelik gebore: Reinet op 12 Desember 1946 en Peter op 13 Januarie 1950.

Die halwe kring het 'n gemengde ontvangs geniet. Dis in Die Burger erg negatief geresenseer deur EC Pienaar, terwyl HA Mulder in Die Suiderstem gemeen het dat die bundel Louw "sy eie plek gee aan die top van die Afrikaanse poësie en dit, vir my gevoel, in die ry van die groot bundels Nederlandse liriek as hul gelyke plaas". In dieselfde tyd het 'n polemiek uitgebreek omdat Louw 'n halwe Hertzogprys vir Alleenspraak geweier het. Vir Die halwe kring het hy darem die volle prys ontvang (kyk by "Hertzogpryse"). Nog in 1937 het Louw begin met die vertaling uit Frans van Aimer van Paul Géraldy vir die VVB; dit het in 1939 as Hélène verskyn.

'n Mens kan die jare dertig moeilik los dink van die ideologiese dwaalweë waarop ook digters en ander intellektuele indertyd beland het. Party het hulle aangetrokke gevoel tot die kommunisme, ander het gekwalifiseerde steun aan fascisme gegee. Onder laasgenoemde was Benedetto Croce, Jean Cocteau, Luigi Pirandello, Giovanni Gentile, WB Yeats en TS Eliot. Pro-fascistiese intellektuele was Oswald Spengler, Ezra Pound en Martin Heidegger. In "Naggesprek" erken WEG Louw - "desnoods met skaamte" - dat ook hy en sy broer meegevoer is deur die tydgees. Hulle het vas geglo dat twee van hul eie ideale in die vroeë Nazi-Duitsland te vinde was: "die trots op eie nasieskap" en "die sorg vir dié wat swaarkry, aan die kortste end trek" (WEG Louw 1972:15).

Die optrede van Hitler het hulle ontnugter - eers Gladstone en heelwat later ook Louw.

Dit was in daardie jare dat Louw in persoonlike briewe aan Gladstone (wat in Amsterdam student was) uitlatings oor die Jode gemaak het wat dekades daarna, ná die onthulling daarvan deur Gerrit Olivier (1992), opspraak verwek het. Louw was nie die enigste nie: in die jare twintig en dertig het baie Westerse leiers en instellings dinge oor Jode kwytgeraak wat hulle later moes betreur. Onder hulle was Winston Churchill en die Londense Times. Die houding van Louw en ander het eerder voortgekom uit ekonomiese as "rasse"-oorwegings. Baie Afrikaners het gemeen dat Jode 'n houvas op die ekonomie het. Ook Engelse koerante soos The Star en die Cape Times het wetgewing van 1930 teen immigrasie uit verskeie lande gesteun. Groot onrus het veral ontstaan toe baie Jode ná die bewindsoorname van Hitler ook na SuidAfrika gekom het. Betekenisvol is dit egter dat Louw nooit iets teen Jode gepubliseer het nie. Hul lotgevalle het hom gou van houding laat verander sodat hy hul lot in 1946 as waarskuwing aan Afrikaners voorhou (daaroor later meer).

Dit is nie verbasend nie dat Louw soos die meerderheid Afrikaners weens hul anti-Britse gevoel in 1939 teen die Suid-Afrikaanse deelname aan die Tweede Wêreldoorlog gekant was. Hy het die Volksraad se oorlogsbesluit beskou as 'n groot neerlaag en gesê: "Die gemeenste van alle dinge op aarde is: om vir dié te veg wat jou mense verower het, om óp te staan, 'op aandag', vir die lied wat met wapengeweld deur vreemdes op jou afgedwing is". Hy was egter baie geskok oor die Duitse inval in die neutrale Nederland en België op 10 Mei 1940. In Die Huisgenoot met sy pro-Nederlandse redakteur Markus Viljoen skryf hy 'n lang stuk oor Nederland se meelewing met die Afrikaners in die Anglo-Boereoorlog, die hoë gehalte van die Nederlandse literatuur en die kommer oor die lot van Nederlandse skrywers. Daar bestaan by Afrikaners die begeerte om as dit moontlik is, tydelik die Nederlandse literatuur in 
ballingskap te bewaar, selfs om Nederlandse skrywers wat na Suid-Afrika kan kom, te help totdat hulle na hul vaderland kan terugkeer. Louw was 'n medewerker aan die bundel Tussen die engtes. 'n Afrikaanse versameling ten behoewe van Nederlandse skrywers (1940). Ná die oorlog is die inkomste daaruit gebruik om 'n deel van die koste te dek van besoeke van Nederlandse digters soos A Roland Holst aan Suid-Afrika.

Louw se bydrae in die bundel was getitel "Die koms van Raka". Dit was 'n deel van een van die groot werke waarmee Louw in die vroeë 1940's Afrikaans verryk het. Hy het dit aan die einde van 1939 en die begin van 1940 aangepak, en einde 1940 en begin 1941 voltooi. Die werk daaraan was vir hom 'n groot vreugde. Hy het soggens vroeg op die stoep van sy gehuurde bungalow by Clifton sit en werk. Teen elfuur was daar gewoonlik al vordering, teen twaalfuur kon hy Truida bel en sê: "Daar is 15 of 20 of 50 versreëls klaar!" Teen eenuur was dit dalk 80 reëls; "glo op 'n dag 160 of 200 reëls in 'n ekstase klaargekry". Smiddae het hy uitgespan en gaan swem of stap en saans vakerig lê en dink aan wat hy die volgende dag moes doen (322).

Raka (1941) is baie gunstig ontvang en dit het Louw se mees gelese werk geword. Dit het selfs die status van 'n trefferverkoper bereik. Kannemeyer noem Raka as epiese gedig "een van die grootste prestasies van die Afrikaanse letterkunde" (2005:154). Daar is verskeie interpretasies van die boek gegee. Louw noem dit 'n simboliese vers; "baie van die verklarings wat al van Raka gegee is, bevat iets van die waarheid, maar dit is verkeerd om een daarvan tot enigste en finale verklaring te maak" (1986a:547).

Die bundel Gestaltes en diere (1942) word soos Raka beskou as 'n hoogtepunt in die Afrikaanse poësie. Daarin verskyn talle van sy grootste en bekendste gedigte soos "Die hond van God", "Die swart luiperd" en "Ballade van die bose". Dié gedig, wat volgens 'n Nederlandse kritikus tot die wêreldliteratuur behoort, het die eerste keer verskyn in die vakansie-uitgawe van Die Huisgenoot van 6 Desember 1940.

Grové skryf (1981:338) dat die digter in die vyf digwerke wat van 1935 af verskyn het, 'n skouspelagtige ontwikkeling deurmaak.

Van die lied kom hy oor die koorspel en die dramatiese monoloog tot die epos en die moderne ballade; van die liriese belydenis tot die objektiewe beelding; van die 'alleenspraak' tot die 'gestalte'. Telkens kan dieselfde motief terugkeer: die besef van geroepenheid, die stryd met God, die besef van die verstrengeldheid van goed en kwaad, van die donker ondergrond waaruit die geestelike lewe moet opstaan, dog telkens anders gesien en verbeeld soos die spanning in nuutgekonsipieerde gestaltes geban word: die profeet, die jagter, die drinker, die inkwisiteur. En in dié proses word van die beroemdste gedigte in Afrikaans voortgebring.

Louw was in die jare veertig, veral ná Raka en Gestaltes en diere, vasgeval in 'n "moeras van werk" soos hy dit in 1943 in 'n brief noem. Hy het verskeie artikels geskryf, oor onder andere Jan FE Celliers en C Louis Leipoldt, asook 'n lang inleiding oor Marsman vir 'n SuidAfrikaanse uitgawe van dié digter se poësie en prosa. Hoewel hy aanvanklik huiwerig was vir radiowerk, bied hy en Truida 'n reeks praatjies aan oor temas wat groot skrywers, komponiste en skilders deur die eeue heen oor en oor gebruik het: die Faust- en Prometheus-legendes, Don Juan, die vliegende Hollander, Simson, Romeo en Juliet en Uilspieël.

Reeds aan die einde van 1941 begin hy werk aan die versdrama Germanicus, wat hy wel later in die jare veertig voltooi, maar wat eers in 1956 as boek verskyn. In 1951 word ook die vers-hoorspel Dias uitgegee. Heelwat tyd wy hy ook aan stukke wat hy vir die Afrikaanse Kinderensiklopedie moes skryf - 'n publikasie wat die Nasionale Pers op inisiatief van Louw 
se vriend CF Albertyn aangepak het, hoewel die voorstel daarvoor oorspronklik op 'n vergadering van die Afrikaner-Broederbond gedoen is. Van dié organisasie was Louw sedert 1934 'n lid. Onder meer skryf Louw oor die Afrikaanse taalbewegings - wat hom prikkel om verder te dink oor die verbreding van die Afrikaanse beweging in die toekoms. In 1943 het hy in ' $n$ toespraak die mening van Langenhoven oor Afrikaans as 'n witmanstaal bevraagteken.

'n Ou ideaal van die Louw-broers was 'n eie tydskrif. Twee struikelblokke, gebrek aan geld en 'n tekort aan papier, het teen die einde van die oorlog verval. Genoeg papier is gevind en Gladstone kon geld by sy vader leen, en van Fred le Roux en Albert Wessels kon hulle rentevrye lenings kry. Die eerste redaksie van dié tydskrif, Standpunte, het bestaan uit die twee broers en HA Mulder. Die eerste uitgawe het in Desember 1945 verskyn. Louw verklaar in die eerste hoofartikel dat die blad die vrye geestelike en intellektuele lewe wil dien.

Ons glo dat die rykste kulture ontstaan in tydperke waarin 'eens-wees' en 'ja-sê' nie die hoogste waardes is nie, en waarin die naas-mekaar-bestaan van botsende wêreldbeskouings nie as tekens van dekadensie beskou word nie. Daarom sal ons die geleentheid verskaf om die mees uiteenlopende standpunte te stel. (1986b:505)

Louw was self een van die bydraers. In Oktober 1946 skryf hy oor politieke literatuur en die intellektuele lewe in Suid-Afrika en betrek die nasionalisme en die liberalisme. Die liberale eise van "vryheid", "gelyke regte" en "gelyke kanse" vir almal sou meebring dat die Afrikanervolk en die Engelse volksdeel "sou versink tot magtelose minderhede tussen 'n massa swartes". Vir die Afrikaners sou dit neerkom op nasionale selfmoord en ook individuele vernietiging. As die Afrikaner hier so 'n minderheid word, "dan weet hy dat hy so hulpeloos soos die Jood in Duitsland sal wees". Wat ons in Suid-Afrika het, sê Louw, is 'n "tipiese 'tragiese' situasie in die geskiedenis: twee 'regte' wat onverenigbaar teenoor mekaar staan. 'n Oplossing wat een van die twee ten koste van die ander laat seëvier, word self onregverdig". Die latere apartheidsbeleid het hy verwerp en vermoedelik partisie voorgestaan.

Die waarde van Louw se werk is in baie kringe misken. Dit was vir hom 'n groot verrassing toe hy op 28 Desember 1947 'n mededeling van die Rijksuniversiteit van Utrecht ontvang dat dié universiteit aan hom 'n eredoktorsgraad toeken. Hy het later gesê die eerbewys het gekom

op 'n tyd dat ek weer werklik moes twyfel daaraan of ek iets binne my volk bereik of kan bereik. Daar was 'n tyd [...] dat daar eintlik 'n kwaai veldtog was om te spot met die literatuur van ons groep en bowenal met myne, om dit te beskuldig van gewilde duisterheid, van 'n poging om die volk te mislei en te bedrieg en 'n beskuldiging dat dit onnasionaal is, ensovoorts en daar was oomblikke dat ek byna wou weghardloop. En dan die gevoel dat daar tog êrens 'n eggo kom, dat jy nie werklik in 'n lugleegte inpraat en dat êrens mense of iemand kom met begrip. (1986b:465)

Louw se vriende was hoog in hul skik en 'n klein partytjie is gehou in die voorkamer van DJ Opperman en sy vrou Marié se woonstel. Aanwesig was Louw en Truida, Jan Greshoff en sy vrou Aty, wat na Suid-Afrika gekom het enkele weke voor die uitbreek van die oorlog, Fred en Ria le Roux en Gladstone en sy vrou Rosa. Ses kinders van die vier Afrikaanse egpare het vrolik rondbaljaar en die grootmense kon mekaar skaars hoor praat. Louw het Opperman se poësie hoog aangeslaan en hulle was goeie vriende.

By die gradeplegtigheid op 20 September 1948 het prof. WAP Smit gesê dat die universiteit met dié toekenning uitdrukking gee aan die belangstelling en groot waardering van die Nederlandse wetenskap ten aansien van die ontwikkeling in die jongste Afrikaanse letterkunde, "waarvan Gij de voorman zijt en symbool"(496). 


\section{VERNUWENDE POËSIE EN DENKE}

In 1949 het Louw 'n aanbod aanvaar om professor in die Zuidafrikaanse taal- en letterkunde aan die Gemeentelijke Universiteit van Amsterdam te word. Sy vrou en kinders kon nie saam met hom vertrek nie, want Peter, skaars drie weke oud, het 'n vorm van geelsug gehad en die dokter het besluit hy kan nie die lang seereis onderneem nie. Louw was dus 'n tyd lank alleen nadat hy op 20 Februarie 1950 in Amsterdam aangekom het.

Binne 'n paar weke het 'n liefdesverhouding ontstaan tussen hom en Sheila Cussons, wat later bekend sou word as digter. Sy was getroud met Stoffel Nienaber, van wie sy geskei is. Toe Truida in April ná haar aankoms bewus word van die verhouding, wou sy dadelik teruggaan, maar kon nie plek op 'n skip kry voor die einde van die jaar nie. Sy het dus gebly en die huwelik is nie ontbind nie. In die destyds heel konserwatiewe Afrikaanse en Nederlandse gemeenskappe is kwaai kritiek op Louw uitgespreek en daar was selfs sprake dat hy sy werk kon verloor. 'n Vermanende brief van Greshoff het tot 'n breuk tussen die twee digters gelei.

Die verhouding met Cussons was nie altyd heg nie, maar vir Louw was dit 'n kreatiewe stimulus. Daniel Hugo (2001:20-21) meen dat die verhouding met Sheila die volle agt jaar van Louw se verblyf in Nederland gekleur het

met ekstase en verdriet. Dit sou ook die Afrikaanse letterkunde onherroeplik beïnvloed. Sonder Sheila Cussons sou heelwat van die gedigte in Nuwe Verse (1954) en Tristia (1962) nooit tot stand gekom het nie. Sonder Van Wyk Louw sou Cussons nie van haar mooiste gedigte geskryf het nie.

In Nuwe verse is Klipwerk opgeneem, wat Louw self as baie belangrik beskou het. Hy het begin skryf daaraan tydens 'n besoek van hom en Cussons aan Parys in Desember 1950. Daar het hy die straatlewe ervaar "met mense van byna elke nasie onder die son". Die vraag het by sy kop "ingeklouter":

Wát is julle, Afrikaners... een volk tussen honderde of duisende volke? [...] Watter eienheid het julle? Kan julle nie maar verdwyn sonder verlies vir die wêreld nie? Toe het ek die eie wêreld wat ek ken, begin oordink. [...] 'n Volk moet iets in hom hê, al is dit die fynste nuanse van 'n openbaring van die lewe se rykheid.

Dít het Louw gevind in die Rôeveldse wêreld en taal -

soms kru; vol seksuele verwysings en maskerings; obsene dinge; wreedheid; droewighede; vrolikheid; bygeloof; liefdesjaloesie; haat; spot; elementêre leef binne sensasies.

As ons taalgebruik die soepelheid, konkreetheid, soms felheid van daardie ou taal verloor; as ons alleen die gladde, abstrakte, 'beskaafde' taal van die koerant en dokument gebruik - 'n taal waar die Engelse ribbetjies maar té sigbaar is onder die dun velletjie Afrikaans - dan sal ons werklik een van ons bestaansredes as volk verloor het. (Louw 1986a:552554)

Die voortbestaan van Afrikaans en die Afrikaners was een van die temas in 'n reeks opstelle van hom in Die Huisgenoot. In 'n mate is hierdie opstelle as byverdienste geskryf, want geld was gedurig 'n kwelling in sy Amsterdamse jare. Die stukke het van 20 Julie 1951 tot 18 Desember 1953 onder die opskrif "Die oop gesprek" verskyn. (Gewoonlik het hy feitlik uit die vuis uit sy aantekeninge gedikteer en Truida het dit getik.) Baie Huisgenoot-stukke het gehandel oor literêre temas en die invloedrykste daarvan was die reeks "Die 'mens' agter die boek". Dit was gerig teen psigologisme in letterkundige beskouings en kritiek. 
Louw verwoord sy nuwe kyk op nasionalisme in "Rondom die begrip "nasionaal". In 1936 het hy nog gemeen nasionalisme stel dieselfde absolute eise as 'n godsdiens, maar hy erken dis verkeerd. Die nasionalisme moet hom soos enige ander politieke strewe voor die "regbank van die waardes" verantwoord. Hy sê ook dat 'n mens 'n volk liefhet nie omdat jy dink hy is beter as ander volke nie, maar jy het hom lief om sy ellende. Hy antwoord ook op die verwyt dat die nasionalisme beperkend is. Wanneer 'n mens die waarde van nasionale regte soos onderwys in jou eie taal insien, "nie alleen as regte wat jou eie groep toekom nie, maar as universele menslike regte, dan is jy reeds uit die beperktheid van 'n eie groep uit; en jy sal hulle dan nie alleen vir jou eie groep opeis nie" (Louw 1986a:419-431).

Die reeks "Kultuur en krisis" is in 1952 geskryf na aanleiding van die "konstitusionele krisis" in Suid-Afrika. Die regering het 'n wet laat aanneem wat die bruin kiesers van die Kaapprovinsie op 'n afsonderlike kieserslys plaas. Dit was in stryd met 'n bepaling van die 1909-grondwet en is deur die hof onkonstitusioneel verklaar. Louw was sterk teen dié wet, al sê hy dit nie in sy reeks nie. Tog het dié reeks in die volgende dertig jaar 'n groot rol in die politieke debat gespeel.

Hy verduidelik soos volg wat hy met so 'n krisis bedoel. "'n Nasionale krisis, so lyk dit my, kan alleen 'n tyd wees wanneer die voortbestaan self van 'n volk op die spel kom; wanneer een van die moontlike uitslae die ondergang van die volk kan meebring." Hy onderskei drie soorte krisisse. Die eerste is die "letterlike uitroei van die mense waardeur die volksgees gedra word”. Die tweede is die krisis van vertwyfeling. Dit kom voor wanneer baie lede van 'n gemeenskap voel dat dit nie die moeite werd is om as 'n groep met 'n eie taal voort te bestaan nie. Ten slotte is daar 'n etiese krisis: "om te glo dat blote voortbestaan verkieslik is bo die voortbestaan in geregtigheid" (Louw 1986a: 450-466).

Die Huisgenoot-stukke en ander opstelle het in 1955 in Maskers van die erns en in 1958 in drie bundels verskyn: Swaarte- en ligpunte, 'n Wêreld deur glas en Liberale nasionalisme. Verskeie ander stukke, onder meer sy radiopraatjies van die jare vyftig, is postuum uitgegee. Daaronder is "Die opkoms van tale" wat handel oor taalbewegings en veral die Afrikaanse beweging. Vir Die mens agter die boek (1956) en Maskers van die erns is die Hertzogprys vir kritiese prosa en essays vir 1957-58 aan hom toegeken. Lojale verset en Berigte te velde is vir dié prys ook in aanmerking geneem.

Louw het dié nuus in Junie 1958 verneem, 'n paar weke voordat hy na Suid-Afrika vertrek het om hoof van die Departement Afrikaans en Nederlands aan die Universiteit van die Witwatersrand (Wits) te word in die plek van CM van den Heever wat die vorige jaar oorlede is. Truida en hul twee kinders het eers in Januarie 1959 gekom. Sy was aanvanklik onwillig om terug te kom, en hy moes haar feitlik smeek. Mettertyd is die verhouding herstel en ná 'n paar maande het hulle, soos Truida dit stel, "weer minnaars geword". Volgens alle informante het Truida tot met Louw se dood al meer oor sy belange gewaak (Steyn 1998: 872-873).

Heelparty gedigte wat Louw in Nederland as 't ware "in ballingskap" geskryf het, is opgeneem in Gedigte, 'n bloemlesing wat in 1960 op Louw se versoek deur Elize Botha en AP Grové saamgestel is uit gepubliseerde en nuwe poësie wat die kern van die bundel Tristia (1962) vorm. Dié titel verwys na 'n bundel wat die Romeinse digter Ovidius tydens sy ballingskap geskryf het. Gerrit Olivier wys op die "ongelooflik komplekse rykdom" van die bundel en verklaar dat die materiaal wat daarin verwerk word, "verbluffend van omvang en verskeidenheid" is. In die beste gedigte in Tristia bereik Louw “" $n$ weergalose samespanning van woord, beeld en segging, soos in die groot gedig 'Saltimbanque en vriendin"' (2016: 691 en 692).

Sy intreerede by Wits, "Oor moeilike literatuur: die "verwysingsmoeilikheid"” van 1959, is byna 'n teoretiese wegbereider vir Tristia. Die literatuur "sleep van alles met hom mee" en 
sy verwysingsveld is onbegrens. Die vraag na 'n grens waarbuite die digter hom nie durf waag nie, is onbeantwoordbaar, maar die "menslike denk is van so 'n aard dat sodra hy 'n grens kan dink, hy ook die land daaragter dink ... nee, reeds begin verken het” (Louw 1986b:408-9). By die skep van Tristia-verse met hul soms skynbaar duistere verwysings moes Louw se ontsaglike belesenheid en belangstellingsveld en fotografiese geheue 'n rol gespeel het.

Volgens Grové (1981:338) bevat Tristia "van die rypste en diepsinnigste gedigte in Afrikaans, byvoorbeeld 'Groot ode', wat die bundel besluit en wat met grootse musikale bewegings, sy deurvlegtende motiewe van lewe, dood en ewigheid gesien kan word as die sluitstuk van L. se poësie". Die bundel is baie gunstig ontvang en in 1965 met die Hertzogprys vir poësie bekroon. Met die oorhandiging het TT Cloete gesê Louw se digterskap, wat al herhaaldelik so vol verrassings was, gaan met Tristia vir die soveelste keer 'n nuwe koers in. Hy is "vandag saam met veel jonger digters een van ons jongstes".

Cloete verwys hier na die poësie en prosa van die nuwe letterkundige generasie: die sestigers. Louw het die teenstand onthou wat hy en die ander dertigers moes ervaar en het moeite gedoen om wanopvattings oor die prosa en oor vernuwing te bestry. Sy stukke is gebundel in Vernuwing in die prosa (1961). Etienne Leroux verklaar dat Louw se behandeling van sy eerste boeke vir hom 'n aansporing was om voort te gaan met sy skryfwerk, onder meer Sewe dae by die Silbersteins. Louw se voorspraak vir 'n Hertzogprys aan dié roman in 1964 het tot een van die grootste polemieke in die Afrikaanse literatuurgeskiedenis gelei.

In 1965 het hy vir 'n ander sestiger, Breyten Breytenbach, in die bresse getree. Die regering het 'n visum aan sy vrou, Yolande, geweier om Suid-Afrika te besoek omdat sy uit Viëtnam kom. Louw het in 'n koerantbrief die regering gekritiseer "as Afrikaner", maar ook "namens die Afrikaanse literatuur wat sy eie eer en waardigheid het". Hy skryf (Dagbreek en Sondagnuus, 30 Mei 1965) hy praat

met pyn en skaamte. Die Afrikaanse nasionalisme waarin ek opgegroei het en waarbinne ek hoop om te sterwe, was vir my die grootste beweging binne ons geskiedenis en 'n teken van uitgroei, van steeds voller lewe. Word dit nou 'n verstarde ideologie, wat deur amptenare met duimstokke afgemeet kan word?

Louw het jare lank teen sensuur gewaarsku. Met die ontvangs van die Hertzogprys vir Germanicus (kyk by "Hertzogpryse") het hy in 1960 gesê:

Laat ons die vryheid van die Afrikaanse boek jaloers bewaar; laat ons nie in 'n stryd teen 'vuilskrywery' 'n hele literatuur dwing om onder die juk van 'n preventiewe sens deur te gaan nie. Dit sou wees of 'n mens jou drinkwater met 'n ontsmettingsmiddel wil ontsmet. (1986a:904)

In Die Burger (18 Maart 1963) lewer hy vergeefs skerp kritiek op dreigende sensuurwetgewing. "Ek twyfel of selfs Milner 'n meer doeltreffende middel sou kon bedink het om Afrikaans te kniehalter en aan Engels in Suid-Afrika vrye teuels te gee." Hy het gevrees Afrikaanse skrywers sou liewer Engels gebruik.

Om die slegste te probeer verhelp, het Louw hom beywer om goeie letterkundiges oor te haal om in die Publikasieraad te dien. Prof. G Dekker was die eerste voorsitter. Die eerste raad is so saamgestel dat Louw in Die Burger (22 Oktober 1963) kon aanvoer dat die literature in al die Suid-Afrikaanse tale onbelemmerd kan voortgaan. Hy laat dit blyk dat hy prinsipieel teen sensuur bly; latere rade kan anders lyk. Binne enkele jare het die raad onder nuwe voorsitters ook Afrikaanse boeke verbied. Louw se vrees dat Afrikaanse skrywers sou oorloop na Engels is egter nie bewaarheid nie. 
Vernuwing in die prosa is saam met Die mens agter die boek belangrike bydraes tot die skepping van die Afrikaanse letterkundige kanon - waarop Van Coller (2009) uitvoerig ingaan. Louw het die kanon verder help vorm deur 'n bloemlesing, Treknet, saam met E Lindenberg, asook 'n reeks radiopraatjies oor die poësie in 1961.

Louw het verskeie soorte werk vir die radio gelewer. Daaronder is die hoorspele Kruger breek die pad oop (1964), Dagboek van 'n soldaat (1961), Lewenslyn (1962) en Die held (1962). In 1965 verskyn Asterion, die libretto vir 'n radiofoniese opera waarvoor Henk Badings die musiek gekomponeer het. Die stuk is opgedra aan die nagedagtenis van sy dogter Ria, wat oorlede is in 1964 en getroud was met Ampie Muller, 'n professor in sielkunde.

Die eerste van drie geleentheidstukke, Koning-Eenoog of Nie vir geleerdes is in 1960 opgevoer by die Uniefees wat die totstandkoming van die Unie van Suid-Afrika in 1910 gedenk het. Die pluimsaad waai ver is in 1966 opgevoer met die Republiekfees en Berei in die woestyn (1968) 'n "Sinne-en-Wa-spel", geskep met die oog op die "waterjaar".

Louw verduidelik in die program vir die opvoering van Die pluimsaad waai ver dat pres. MT Steyn, laaste president van die Oranje-Vrystaat, wel 'n belangrike rol speel, maar dat die Afrikaanse volk self die held van die stuk is. "Hierdie volk is teen sy sin en sonder vorige ervaring in 'n stryd met 'n wêreldmag gedompel. Hoe hy hom verweer het, wat hy moes leer en afleer, ook die skeurings wat daar binne hom gekom het - dit is die tema".

Dit begin met die vraag: "Wat is 'n volk?" Dit is iets waaroor hy sy hele lewe lank sou nadink: "oor hoe vreemd gemeng dié ding is wat ons 'n 'volk' noem". In Pluimsaad behoort almal wat aan die Vrystaatse kant aan die Anglo-Boereoorlog deelneem, tot die Vrystaatse Afrikaners. Dit sluit naas die Afrikaners ook Engelssprekendes, Kaapse rebelle, Nederlanders en bruin mense in. Een van die karakters, Ruiter, is bruin. Die letterkundige Merwe Scholtz beskou die drama as 'n "breë demokratiese definisie van die Afrikanervolk" (Steyn 1998:10451046).

Die opvoering het in 1966 heelwat kritiek uitgelok, onder andere van die eerste minister, dr. HF Verwoerd in 'n feesrede. Die meeste koerantbriewe was egter pro-Louw en hy is verdedig deur belangrike figure soos prof. Gerrit Viljoen, rektor van die Randse Afrikaanse Universiteit, en prof. FIJ van Rensburg, skrywer van verskeie werke oor Louw. Maar reeds van 1960 af was Louw se opvattings oor "volk" onaanvaarbaar vir die regerende party. In daardie jaar het Louw in die voorwoord tot DP Botha se Die opkoms van ons derde stand die NP-beleid teenoor bruin mense gekritiseer. Volgens hom het "oortuigde Afrikaner- en Suid-Afrikaanse nasionaliste" spontaan gesê: "Ons het verkeerd gehandel teenoor die Bruinmense; ons het hulle verwaarloos en afgestoot." Hy het van die geykte opvatting van "volk" afgewyk deur wit én bruin mense as lede van die volk te beskou. In die laaste jare van sy lewe het Louw die "verligtes" se kant gekies in die bitter broedertwis tussen hulle en die "verkramptes".

Berei in die woestyn was volgens Grové (1981:339) "daarop gemik om met die oproep van allegoriese figure, die volk se sondes te ontbloot en om teen die agtergrond van die $\mathrm{Ou}$ Testament en by monde van die Profeet die straf aan te kondig in die vorm van Droogte en Hongersnood".

Van Februarie tot April 1970 het hy 'n reeks van nege praatjies, Rondom eie werk vir die Afrikaanse radiodiens van die SAUK gelewer. Hy het die praatjies beskou as "hier en daar herinnering; terugkyk op aspekte van 'n lewe en werk. En dis effens afkrap van groenspaan". Hy het uitgewei oor onder meer sy taalagtergrond, na aanleiding van Raka oor die simbool; oor Klipwerk en die Pluimsaad-debat. Die reeks is as boek en 'n reeks plate uitgegee.

Louw het op 13 November 1961 'n ernstige hartaanval gehad en daarna hartprobleme ondervind. Op 18 Junie 1970 is hy vroeg die oggend oorlede - 'n week ná sy 64ste verjaarsdag 
en drie weke na die dood van sy oudste broer Koos, ook aan sy hart. Hul moeder, die 88-jarige tant Poppie, bedlêend ná 'n beroerte, is op 28 Julie oorlede sonder dat sy meegedeel kon word Louw is oorlede. Die roudiens was op 22 Junie in die NG Kerk Linden en is gelei deur sy swaer ds. WFH Huyzers van die Nederduitsch Hervormde Kerk.

Louw bly aktueel in die letterkunde en kultuurlewe. Louise Viljoen (2008) lewer 'n fassinerende verslag van hoe Louw voortleef in intertekstuele verwysings, sitering, parodieë en titels, onder meer in werk van Breyten Breytenbach, Sheila Cussons, parodieë van "Vroegherfs" deur Johan van Wyk en Joan Hambidge en titels soos Hennie Aucamp se Dalk gaan niks verlore nie.

Ná 1970 was "Kultuur en krisis" 'n tema in die politieke debat. Giliomee skryf dat Louw se frases oor voortbestaan in geregtigheid en lojale verset in die jare sewentig vryelik in die openbare debat gebruik is - "dikwels opportunisties". Redakteurs het dit soms gebruik om NP-eenheid en bedenklike hervormings te verdedig (2004:536). Intellektuele soos Johan Degenaar en André du Toit, wat albei apartheid verwerp het, het op Louw gesteun in hul argumente om 'n liberale inklusiewe demokrasie in te stel (2004:423). Breyten Breytenbach het dit in 1975 in sy verhoor aangehaal. Reeds voordat Breytenbach na Suid-Afrika gekom het om 'n struktuur vir 'n ondergrondse beweging te vestig, het sekere ANC-leiers die veiligheidspolisie ingelig. Hy is gevang en verhoor en het hom in 'n desperate pleidooi op Louw beroep: "Dit is dalk paradoksaal, maar vir my het dit gegaan om die voortbestaan van ons volk, 'n voortbestaan met regverdigheid soos Van Wyk Louw dit uitgedruk het, oor die gehalte en inhoud van ons beskawing". Die regter het hom nie daaraan gesteur nie (2004:522).

Ná 1994 het die Afrikaners beland in die tweede soort krisis wat Louw onderskei, dié van vertwyfeling - tans weens emigrasie en verengelsing, wat veroorsaak is deur die transformasieideologie en miskenning van taalregte deur vyandiggesinde owerhede. In die diskoers daaroor herleef Louw se opvattings oor so 'n krisis en kultuurmense se antwoord daarop.

Dit is 'n geluk vir die Afrikaanse gemeenskap en taal dat hierdie groot digter en denker sy "één, kort lewe" lank aan dié volk "onherroeplik verbind, ja, verknog" was, soos hy dit in Rondom eie werk verwoord.

\section{HERTZOGPRYSE}

Die mees omstrede Hertzogprys in Louw se skrywersloopbaan was die eerste in 1937. Hy het dit geweier. Hy sou dit in elk geval nie ontvang het nie as die Akademie se letterkundige komitee en 'n breë letterkundige kommissie hul sin gekry het.

Die letterkundige komitee (EC Pienaar, FEJ Malherbe en MSB Kritzinger) het bundels van Louw, ID du Plessis en Elisabeth Eybers oorweeg en Du Plessis aanbeveel. 'n Breë letterkundige kommissie het saamgestem en besluit om die prys toe te ken aan Du Plessis vir Vreemde liefde en Ballades. Die voorsitter van die Akademieraad, dr. EG Jansen, kom toe agter dat die regte prosedure nie gevolg is nie en vra dat die raad die saak weer bespreek. Die raad het besluit die prys moet verdeel word tussen Louw en Du Plessis. Een van die raadslede was die Potchefstroomse letterkundige G Dekker en dis waarskynlik aan hom te danke dat die Akademie die verdienste van Louw tog erken en ook Alleenspraak bekroon het (205-206).

Louw het die aankondiging van die prys uit 'n berig in Die Burger (4 Desember 1937) verneem. Dieselfde dag skryf hy aan die sekretaris van die Akademie dat hy uit die koerant verneem het dat die Akademie 'n deel van die prys aan hom toeken. "Hiermee stel ek u in kennis dat ek dit nie aanvaar nie". As rede voer hy aan: "Die Akademie was weer magteloos om te besluit oor die sake waarin hy hom juis die reg van 'n beslissing toeëien." Aangesien 
die mededeling hom deur die pers bereik het en nie persoonlik nie, gee hy die brief ook aan die pers (Die Burger, 7 Desember 1937).

Malherbe en Pienaar het in hul reaksie uitdrukkings gebruik soos "hooghartige afwysing", “"n eerste bundeltjie" en "komies-teatrale gebaar" en verklaar dat hulle Du Plessis se veelsydige en gesamentlike werk "nommer een plaas" (Die Burger, 11 Desember 1937). Louw antwoord dat die "seniel-histeriese toon" van die twee professore vir die publiek toon wat die gesindheid van die keurkomitee teenoor hom is.

Sy tweede Hertzogprys het Louw in 1940 vir Die halwe kring ontvang. Dit het algemeen byval gevind. Die Huisgenoot het op 22 November 1940 geskryf dat die erkenning die "geesdriftige toestemming" wegdra van almal wat die Afrikaanse digkuns ken. Maar daar kon maklik weer 'n probleem ontstaan het. Pienaar en Malherbe, asook PC Schoonees, was lede van die letterkundige kommissie en het aanbeveel dat die prys verdeel word tussen Louw en Elisabeth Eybers vir Die stil avontuur. Hierdie keer het die breë letterkundige kommissie besluit die prys moet slegs aan Louw gaan. Die raad het dié voorstel eenparig gesteun (308309).

Sy derde Hertzogprys het Louw in 1958 ontvang vir kritiese prosa en essays. Die keurkomitee (Gerhard Beukes, Ernst van Heerden en AP Grové) het die prys toegeken op grond van "sy hele kritiese oeuvre - d.w.s. sy onlangs verskene bundels Die mens agter die boek en Maskers van die erns, met inbegrip ook van sy eerste twee werke, Lojale verset en Berigte te velde". Louw het op 4 Junie 1958 uit Amsterdam sy erkentlikheid teenoor die Akademie en die Akademieraad uitgespreek (837).

Die Hertzogprys vir drama het hy in 1960 ontvang vir Germanicus. Die keurkommissie (FCL Bosman, Hertzog Venter en Audrey Blignault) se besluit was eenparig, maar Venter en Blignault het beswaar gemaak teen 'n stelling van Bosman dat Germanicus sondig teen "daardie onmisbare eis van die drama: die voer tot 'n klimaks as gevolg van 'n botsing. Daar is geen wesentlike botsing in of om Germanicus nie" (904).

Die toekenning van die Hertzogprys vir poësie in 1965 is voorafgegaan deur 'n mate van wrywing in die letterkundige wêreld. Die keurkomitee het bestaan uit AP Grové, Elize Botha en Ernst van Heerden. Die sterkste twee aanspraakmakers was Tristia en DJ Opperman se Dolosse. Volgens Grové het veral Botha sterk gevoel vir Tristia, maar hy self was ten gunste van 'n verdeling van die prys.

Die keurkomitee was in sy verslag van mening dat die twee bundels "hoogtepunte in ons letterkunde" is. 'n Verdeling van die prys is nooit populêr nie, maar "in hierdie geval, waar dit ons twee grootste skrywers geld", sal 'n verdeling "nie een van die twee tot oneer strek nie". Die vertroulike verslag het uitgelek en is in verdraaide vorm aan Louw oorgedra. Hy het sy kollegas, PJ Nienaber en Ernst van Heerden, laat verstaan hy sou die prys weier as dit verdeel word. Die reglement van die Akademie het egter bepaal dat, as die keurkomitee meer as een skrywer aanbeveel, die raad 'n breë komitee benoem aan wie slegs die name van die skrywers, sonder die bevindinge oor hulle, voorgelê moet word. Sewe lede van dié breë komitee het vir Tristia, twee vir Dolosse en een vir albei gestem. In die Akademieraad was daar ook 'n ernstige meningsverskil, maar die prys is aan Louw toegeken. Die verhoudinge was toe al so versuur dat dit moeite gekos het om die regte persoon te vind wat die commendatio kon lewer. Opperman het geweier en vir Louw was Grové onaanvaarbaar. Cloete moes toe optree (1013-1015).

Soos in ander lande was daar dus meermale tweedrag en twis oor die prys, die boeke en die mense agter dié boeke. 


\section{BIBLIOGRAFIE}

Giliomee, Hermann. 2004. Die Afrikaners. 'n Biografie. Kaapstad: Tafelberg.

Grové, A.P. 1981. Louw, Nicolaas Petrus van Wyk, in Suid-Afrikaanse Biografiese Woordeboek IV. Durban / Pretoria: Butterworth vir RGN.

Hugo, Daniel. 2001. In Bekendes se bestes, saamgestel deur Grizéll Azar- Luxton, Kaapse Bibliotekaris, 45 (6):20-21.

Kannemeyer, J.C. 1990. Dokumente van dertig. Kenwyn: Jutalit.

Kannemeyer, J.C. 2005. Die Afrikaanse literatuur 1652-2004. Kaapstad / Pretoria: Human \& Rousseau.

Louw, N.P. van Wyk. 1986a. Versamelde prosa 1. Kaapstad: Tafelberg.

Louw, N.P. van Wyk. 1986b. Versamelde prosa 2. Kaapstad: Human \& Rousseau.

Louw, W.E.G. 1972. Naggesprek en ander gedigte. Kaapstad: Tafelberg.

Olivier, Gerrit. 1992. N.P. van Wyk Louw: Literatuur, filosofie, politiek. Kaapstad / Johannesburg: Human \& Rousseau.

Olivier, Gerrit. 2016. N.P. van Wyk Louw (1906-1970). In Van Coller (2016:673-694).

Schoeman, Karel, 1986. Die lewe van die digter. Kaapstad: Human \& Rousseau.

Steyn, J.C. 1998. Van Wyk Louw - 'n Lewensverhaal. Kaapstad: Tafelberg.

Van Coller, H.P. 2009. Tussenstand. Letterkundige opstelle. Pretoria: Van Schaik.

Van Coller, H.P. (red.). 2016. Perspektief en profiel 2. Pretoria: Van Schaik.

Viljoen, Louise. 2008. Die digterlike gesprek met N.P. van Wyk Louw, Tydskrif vir Geesteswetenskappe, 48(3):267-291. 